\title{
GENETIC VARIATION OF LEAFHOPPER, NEPHOTETTIX VIRESCENS DISTANT ACTIVE TRANSMITTERS FROM ENDEMIC AND NON ENDEMIC AREAS OF RICE TUNGRO DISEASE BASED ON RAPD MARKER
}

\author{
Supriyadi \& Retno Wijayanti \\ Study Program of Agrotechnology, Faculty of Agriculture, Sebelas Maret University (UNS) \\ Jl. Ir. Sutami 36A, Surakarta 57126, Central Java, Indonesia. \\ E-mail: priyadi_hpt@yahoo.co.id
}

\begin{abstract}
Genetic variation of leafhopper, Nephotettix virescens Distant active transmitters from endemic and non endemic areas of rice tungro disease based on RAPD marker. Leafhopper, Nephotettix virescens Distant (Hemiptera: Cicadellidae) plays an important role as a vector of rice tungro virus. However, the characters of $N$. virescens as a vector from endemic and nonendemic areas of tungro disease in Indonesia have not been well characterized and also available information is limited. The objective of this research was to study the character of $N$. virescens active transmitter from endemic and non-endemic of areas tungro disease based on RAPD markers. The $N$. virescens were collected from endemic area of Klaten (Central Java), Sleman (Yogyakarta) and non endemic area of Purwodadi (Central Java) Ngawi (East Java), and Pacitan (East Java). The N. virescens active transmitters were identified by their ability to transmit the virus based on Standard Evaluation System for Rice Tungro Virus, issued by IRRI. The genetic variations of $N$. virescens active transmitters were determined by using RAPD-PCR marker. Result of the research showed that three primers, OPB01, OPB10 and OPC08 amplified successfully of DNA template of $N$. virescens through RAPD-PCR technique. Based on the dendrogram, there were initial facts of possible genetic differences between the populations of $N$. virescens from endemic and non endemic areas of rice tungro disease. The $N$. virescens from endemic area of Klaten and Sleman are similar genetically but different from the $N$. virescens non endemic of Purwodadi, Pacitan and Ngawi.
\end{abstract}

Key words: Nephotettix virescens, tungro virus vector, RAPD-PCR

\begin{abstract}
ABSTRAK
Keragaman genetik wereng hijau, Nephotettix virescens Distant asal wilayah endemik dan non endemik penyakit tungro padi berdasarkan penanda RAPD. Wereng hijau, Nephotettix virescens Distant (Hemiptera: Cicadellidae) berperan lebih penting sebagai vektor virus tungro padi. Namun demikian, karakter $N$. virescens sebagai vektor penyakit tungro padi di Indonesia belum banyak diteliti, sehingga informasi yang tersedia sangat terbatas. Tujuan penelitian ini adalah mempelajari karakter $N$. virescens penular aktif virus tungro padi asal wilayah endemik dan non-endemik penyakit tungro berdasarkan penanda RAPD. Wereng hijau, N. virescens diambil dari daerah endemik Klaten (Jawa Tengah) dan Sleman (Yogyakarta) serta dari non endemik Purwodadi (Jawa Tengah), Ngawi (Jawa Timur), dan Pacitan (Jawa Timur). Individu N. virescens penular aktif diidentifikasi berdasarkan kemampuan menularkan virus tungro sesuai standar Sistem Evaluasi Virus Tungro Padi yang dikeluarkan IRRI. Karakterisasi $N$. virescens penular aktif virus tungro padi didasarkan marka RAPD. Tiga primer, yakni OPB01, OPB10, dan OPC08 digunakan untuk mengamplifikasi DNA N. virescens. Hasil penelitian menunjukkan bahwa primer OPC08 mengamplifikasi lebih banyak bagian DNA $N$. virescens, sehingga memunculkan lebih banyak pita, antar pita juga terpisah jelas sehingga mudah dilakukan skoring untuk analisis data. Berdasarkan analisis dendrogram, ada perbedaan genetik antara populasi $N$. virescens penular aktif asal wilayah endemik dengan asal non-endemik penyakit tungro padi. Wereng hijau, $N$. virescens penular aktif asal wilayah endemik Klaten dan Sleman menunjukkan kemiripan genetik dan berbeda dengan $N$. virescens asal non endemik Purwodadi, Pacitan dan Ngawi.
\end{abstract}

Kata kunci : Nephotettix virescens, vektor virus tungro, RAPD-PCR 


\section{INTRODUCTION}

Leafhopper, Nephotettix virescens Distant (Hemiptera: Cicadellidae) plays an important role as a vector of rice tungro virus (Muralidharan et al., 2003; Widiarta, 2005), while the role of N.virescens as a pest of rice causing direct damage by feeding is less important. The tungro disease is one of the most destructive diseases of rice in South and Southeast Asia, where disease epidemics have occurred since the mid1960s (Azzam \& Chancellor, 2002). In Indonesia, tungro disease is often destruct in endemic areas of Klaten (Central Java) and Sleman (Yogyakarta) and Bali. The Tungro disease caused severe damage in Indonesia with affected area about 16,000 ha in Bali during 1980; 25,000 ha in Bali, Java, Sumatera during 1983-1984; 18,000 ha in Bali, Java, Sumatera, Kalimantan, Irian Jaya during 1985-1986; and 12,340 ha in Central Java in 1995 (Azzam \& Chancellor, 2002), while tungro disease in Central Java cause damage of 1098 hectares in 2010 (Dinas Pertanian Tanaman Pangan Provinsi Jawa Tengah, 2010).

Tungro diseases are caused by two viruses (Hibino, 1996), namely rice tungro spherical virus (RTSV) and rice tungro bacilliform virus (RTBV). Generally, RTBV and RTSV together or RTSV alone is transmitted by leafhopper $N$. virescens (Choi et al., 2009). N. virescens was more effective to transmit the tungro virus (Supriyadi et al., 2004; Widiarta, 2005) and also its population in the field was more dominant than other vectors (Supriyadi et al., 2004; Widiarta, 2005).

Interaction between the vector $N$. virescens and tungro virus can be complex and a specific pattern. In the case of insects borne viruses, Nault (1997) and Fereres \& Moreno (2009), showed a specific pattern of relations between vectors, viral and host plant. The ability of $N$. virescens to transmit tungro virus is individuals, not all individuals in the population to be competent as a vector. Among the population of the leafhopper, there are individuals able to transmit the virus and not able to transmit the virus (Gray \& Banerjee, 1999). Individuals of $N$. virescens that can transmit the virus after acquisition feeding are called active transmitter, while the one that can not transmit a virus called the non-transmitters (Ling, 1972).

The characters of $N$. virescens active transmitters from endemic area of tungro disease in Indonesia have not been well characterized, only limited information was available. Research conducted by Supriyadi et al. (2004) showed relationship between proportion of $N$. virescens active transmitters and endemic areas of tungro disease. Average proportion of $N$. virescens active transmitters from endemic area of tungro disease was $81 \%$, whereas from non endemic area was $52.2 \%$. Meanwhile, the results of different studies indicated that the total protein banding pattern of $N$. virescens active transmitters were different from the non transmitters, but there were no the variation of external morphology (Supriyadi \& Wijayanti, 2010).

The efforts to understand the genetic variation in insect populations often require studies at molecular level. According to Brooker (1999), gene expressions were not always different in morphology, but may also different in the molecular-product or physiological properties. The Randomly Amplified Polymorphic DNA-Polymerase Chain Reaction (RAPD-PCR) is a technique commonly used in studies of genetic variation within or between geographic populations (Naber et al., 2000; Margaritopoulos et al., 2000; Rampelotti et al., 2008). However, studies on molecular tagging conferring $N$. virescens from endemic and non endemic tungro disease were limited and lack information on the character of DNA. There was no report on the use of RAPD markers $N$. virescens from endemic areas of tungro disease in Indonesia was published at this time. Therefore, efforts to identify the active transmitter of $N$. virescens from endemic and non-endemic area of tungro disease needs to be done. The objective of this research was to identify the character of $N$. virescens active transmitters from endemic and non-endemic areas of tungro disease based on RAPD markers.

\section{MATERIAL AND METHODS}

Study Site.The research was conducted from April to November 2010. The population of of $N$. virescens leafhopper used in this study was collected from field in an endemic area of rice tungro disease (Klaten, Central Java and Sleman, Yogyakarta) and non-endemic areas (Pacitan, East Java; Ngawi, East Java; and Purwodadi, Central Java). Mass rearing of $N$. virescens and virus transmission were conducted at the Laboratory of Pests and Plant Diseases, Faculty of Agriculture, University of Sebelas Maret, while identification of the genetic variations of $N$. virescens based on RAPD-PCR markers was performed in the Laboratory of Virology, Department of Plant Protection, Bogor Agricultural University.

Rearing of $N$. virescens Leafhopper. $N$. virescens samples, were collected from field using a sweepnet and then placed in a separate box for each colony. Mass rearing of $N$. virescens was conducted according to 
the methods of Dahal et al. (1997) and Cooter et al. (2000) with modifications of the rice variety and age of seedling to feed the leafhopper. The susceptible cultivar of Cisadane was chosen to feed of the leafhopper. One week-old seedlings of Cisadane were planted in a plastic boxs $3 \times 7 \times 14 \mathrm{~cm}$ in size and then were placed on the rearing box $40 \times 40 \times 40 \mathrm{~cm}$ in size for rearing of N. virescens.

Identification of $N$. virescens Active Transmitters. Identification of $N$. virescens active transmitters was carried out through procedure of transmission test according to Dahal et al. (1997). Adult males of leafhopper were infested on rice that has been infected by tungro virus for three days to take feeding acquisition. After acquisition feeding, the leafhopper was infested individually on healthy seedlings for inoculation feeding for three days. After inoculation feeding, the seedling was planted individually on pots $6 \mathrm{~cm}$ of diameter.

The N.virescens active transmitters were determined by ditermining their ability to transmit tungro virus after acquisition feeding, according to the criteria of Ling (1972). The ability of $N$. virescens to transmit the virus was based on criteria of the Standard Evaluation System (SES), with a score of 3, namely shortening of $1-10 \%$ of the top leaf, abnormal seedling by shortened growth, but no yellowish leaf (IRRI, 1996). The $N$. virescens active transmitters that have been identified were stored in $90 \%$ alcohol and used as a sample of DNA extraction.

DNA Extraction. Procedure of RAPD-PCR was conducted through three main steps, namely DNA extraction, PCR amplification and DNA visualization. The first step of RAPD-PCR was the preparation of the target DNA template. The $N$. virescens active transmitter male was used to isolate DNA template. Males $N$. virescens were used as sample because of their smaller body and lower protein contents, so did not interfere in PCR amplification. Genome DNA initially was extracted by modified method from Hidayat $e t$ al. (1996). Homogenizaton of three green leafhoppers, $N$. virescens active transmitter carried out in a microcentrifuge tube using a plastic micro-pestle. Whole insects were macerated in $125 \mu$ l of extraction buffer (2\% CTAB, 1.4 M NaCl, 20 mM EDTA, $100 \mathrm{mM}$ Tris$\mathrm{HCl} \mathrm{pH} \mathrm{8,0)} \mathrm{and} \mathrm{incubated} \mathrm{at} 60{ }^{\circ} \mathrm{C}$ for $30 \mathrm{~min}$. Then was added one volume of chloroform: isoamyl alcohol (24:1) and homogenized by vortex. Subsequently, the samples were centrifuged for $5 \mathrm{~min}$ at $800 \mathrm{rpm}$. Supernatant was transferred to a new tube, were added $10 \mu \mathrm{l}$ of $3 \mathrm{M} \mathrm{NaOAc}$ and $250 \mu \mathrm{l}$ of absolute ethanol, than the supernatants was incubated at $-20{ }^{\circ} \mathrm{C}$ for 30 min and centrifuged at $11,500 \mathrm{rpm}$ for $15 \mathrm{~min}$. After centrifugation, supernatant was discarded and the pellet was washed with $200 \mathrm{ml}$ of $0.2 \mathrm{M}$ solution of ammonium acetate in $70 \%$ ethanol and centrifuged at $11,500 \mathrm{rpm}$ for $2 \mathrm{~min}$. Ethanol was discarded and the pellet was dried in a vacuum pump for $10 \mathrm{~min}$. Pellet was then resuspended in $10 \mathrm{ml}$ of sterile water and stored at $-20{ }^{\circ} \mathrm{C}$. DNA concentration of each sample was quantified by using spectrophotometer, while the quality of DNA was checked by electrophoresis on $1.4 \%$ agarose.

DNA Amplification. The RAPD-PCR amplification was a step to led of DNA bands from identified samples. RAPD-PCR amplification step was to lead DNA band of the sample identified. Amplification of DNA template of $N$. virescens was performed as described by Hidayat et al., (1996). Three selected random primers, namely OPB 01 (GTT TCG CTC C); OPB10 (CTG CTG GGA C), and OPC08 (GGT ACC TGG G), ware used to amplify DNA template. All of the primers were commonly used to amplify of insects (Loxdale \& Lushai, 1998). PCR was carried out in $25 \mu 1$ volume reaction mixture. The reaction mixture contained $18.8 \mu 1 \mathrm{H} 2 \mathrm{O}$, $2.5 \mu$ l Buffer $\mathrm{MgCl} 2,0.5 \mu \mathrm{l}$ dNTP mix $10 \mathrm{mM}, 1 \mu \mathrm{l}$ random primer $10 \mu \mathrm{M}, 0.2 \mu \mathrm{T} \mathrm{Taq}$ DNA polymeration $5 \mathrm{u} / \mu 1$, and $2 \mu 1$ DNAtemplate. Tubes containing reaction mixture were processed into a PCR Thermal Cycler machine. Amplification reactions were conducted by using a GenAmp PCR 9700 thermo cycler programmed to run the following procedure: an initial denaturation 1 cycle at $95{ }^{\circ} \mathrm{C}$ for $5 \mathrm{~min} ; 45$ cycles consisting each of a denaturation step at $94^{\circ} \mathrm{C}$ for $1 \mathrm{~min}$; an annealing step at $36{ }^{\circ} \mathrm{C}$ for $1 \mathrm{~min}$; extension at $72{ }^{\circ} \mathrm{C}$ for $2 \mathrm{~min}$ and final elongation/extension at $72{ }^{\circ} \mathrm{C}$ for $5 \mathrm{~min}$. The products of each PCR were visualized in running electrophoresis in $1.4 \%$ agarose gels at $60 \mathrm{~V}$ for $7 \mathrm{hr}$ in TAE buffer. The gels were stained using ethidium bromide. The results were observed in a transillumination UV light (UV) and photodocumented.

Data Analysis. Data analysis was conducted on the difference variability of $N$. virescens came from endemic and non-endemic areas studied. Gel electrophoresis products, after being photographed were analyzed for the presence of visual criteria. DNA bands profile of $N$. virescens active transmitter from endemic and non endemic were coded binary by visual criteria of presence (1) and absence (0) band for each fragment sizes found in different primary, but only strong and consistent bands considered. The banding pattern 
allowed us to calculate the similarity index of Jaccard (Hidayat et al., 1996; Rampelotti et al., 2008). The procedures were performed using the program NTSYS (version 2.1). Result of the analysis was used to arrange the clusters of $N$. virescens active transmitters in dendrogram based on genetic similarity, representing DNA bands profile. A dendrogram was derived from matrixes that was subjected to cluster analysis by unweighted pair-group method using arithmetic average (UPGMA) method.

\section{RESULTS AND DISCUSSION}

The three primers, namely OPB 01, OPB10 and OPC08 succeeded to amplify DNA target. Overall, the primers of OPB 01, OPB10 and OPC08 produced a number of bands used to identify the variation of DNA bands profile of N.virescens active transmitter from Purwodadi, Ngawi, Pacitan, Sleman and Klaten. The number of polymorphic bands amplified by each primer varied from 1 to 13 bands. OPC08 primer amplified more varied bands than OPB 01 and OPB10 primers. Primer of OPC 08 produced more bands, discrete, scorable, and suitable for identifying variations (Figure 1). The similar research showed that random primer in RAPD-PCR technique was used to study the genetic diversity in the case of intraspecific (Black et al.,1992) and interspecific variation, at least between closely related species, such as Lucilia sericata and L. cuprina (Stevens \& Wall, 1995).

All of DNA banding pattern of $N$. virescens active transmitter from endemic and non endemic areas of rice tungro virus showed variation based on RAPD markers. Results of analysis based on DNA banding pattern of $N$. virescens active transmitters from endemic and non endemic areas of rice tungro disease were showed in Table 1, while the dendrogram based on similarity index of $N$. virescens were showed in Figure 2.
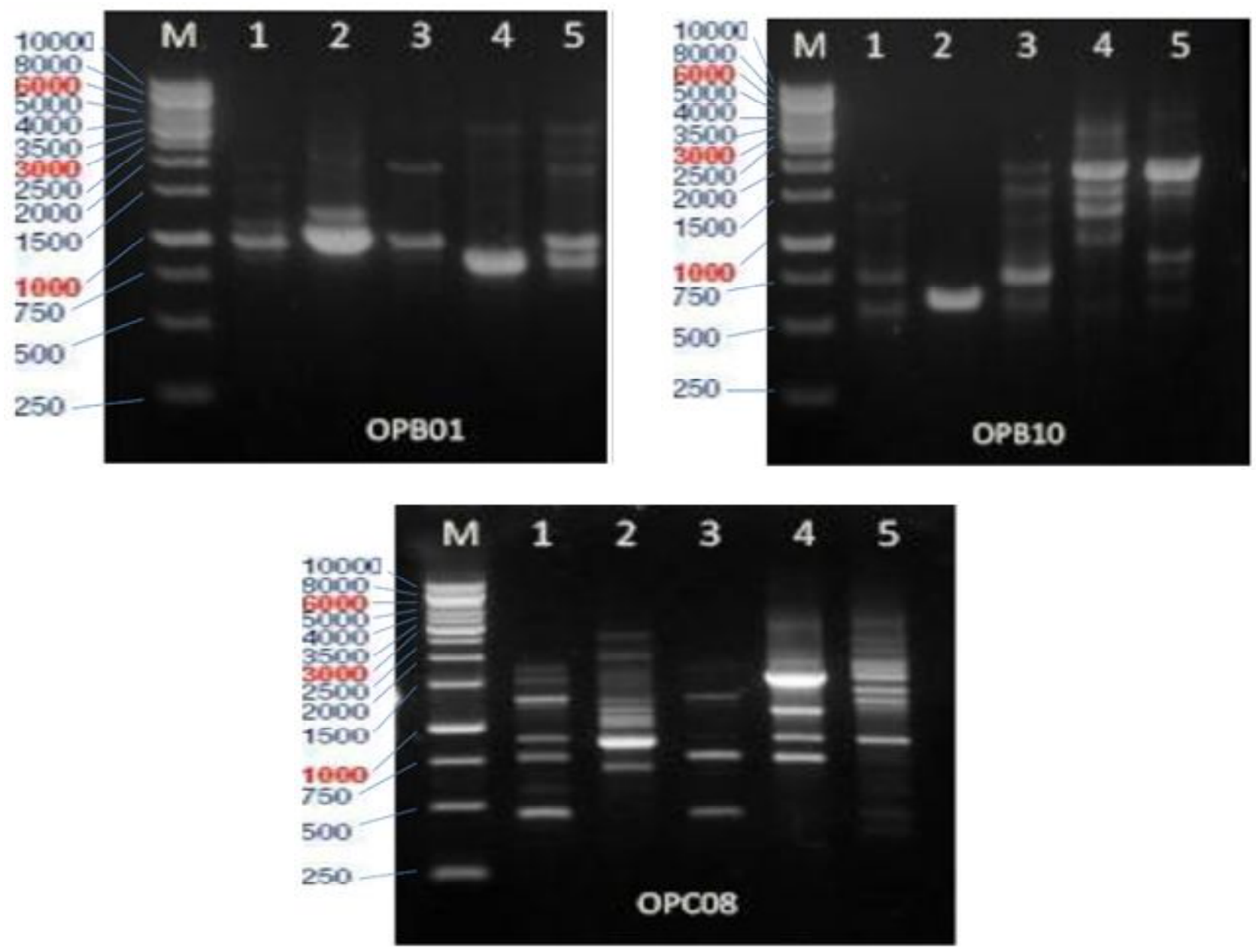

Figure 1. RAPD-PCR banding pattern of leafhopper $N$. virescens from endemics (line $1=$ Purwodadi, $2=$ Ngawi, $3=$ Pacitan) and nonendemics (line $4=$ Sleman, $5=$ Klaten), using pimer OPB 01, OPB 10, and OPC08. 
The pairswise of genetic distance of $N$ virescens active transmitters from endemic (Klaten and Sleman) and non endemic (Purwodadi, Ngawi and Pacitan) ranged from 1.03 to 1.82 (Table 1). The lowest genetic distance occurred between $N$. virescens from Purwadadi and Ngawi that are geographically close, while the highest genetic distance occurred between Ngawi and Pacitan that are geographically distance.

Based on the dendrogram, there were evidence of the relationship between $N$. virescens active transmitters and their origin either from endemic or non endemic areas of rice tungro disease. The $N$. virescens active transmitters from endemic areas of tungro virus from Klaten and Sleman were genetically similar and separately from $N$. virescens from non endemi area (Purwodadi, Pacitan and Ngawi). There were initial fact for the possibility of genetic differences between the populations of $N$. virescens from endemic and non endemic areas of rice tungro disease.
Geographically, the endemics areas of Klaten and Sleman are closely related. However, the non endemic areas of Pacitan are separate from Purwadadi. Meanwhile, the non-endemic areas of Ngawi and Purwodadi are geographically closely related. Overall, the result of this study revealed preliminary information to perform a more in-depth study based on a wider geographical or ecological variation. Whether $N$. virescens active transmitters from endemic areas are genetically distinct with the ones from non-endemic areas need further research. The genetic similarities between $N$. virescens active transmitters from Klaten and Sleman maybe caused by their ecology or geographical closeness. However, in other cases, DNA banding profile produced of RAPD PCR technique has been used to identify the geographic diversity of insects species (Black et al., 1992; Stevens \& Wall, 1995; Rampelotti et al., 2008; Kavar et al., 2006.).

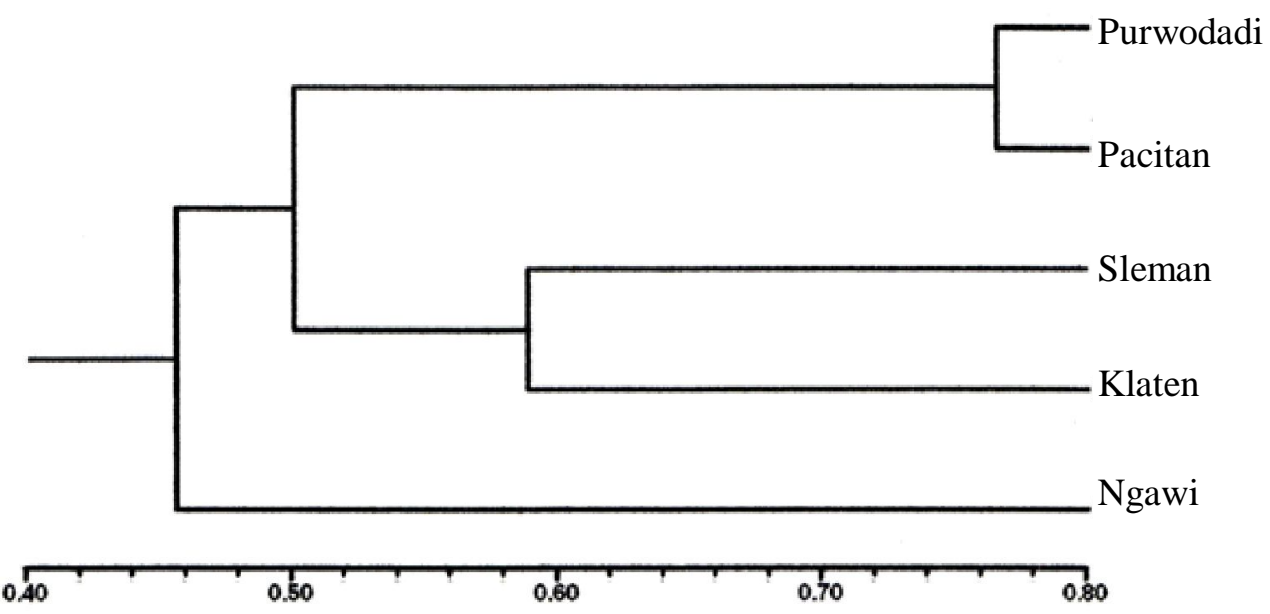

Figure 2. Dendrogram of $N$. virescens active transmitters from endemic area of Klaten and Sleman and non endemic area of Purwodadi, Ngawi and Pacitan based on similarity index of genetic distance.

Table 1. The matrix of genetic distance of $N$. virescens active transmitters from endemic of Klaten and Sleman and non endemic of Purwodadi, Ngawi, and Pacitan

\begin{tabular}{lccccc}
\hline & Purwodadi & Ngawi & Pacitan & Sleman & Klaten \\
\hline Purwodadi & 0.00 & & & & \\
Ngawi & 1.03 & 0.00 & & & \\
Pacitan & 1.50 & 1.82 & 0.00 & & \\
Sleman & 1.15 & 1.37 & 1.44 & 0.00 & \\
Klaten & 1.73 & 1.25 & 1.80 & 1.35 & 0.00 \\
\hline
\end{tabular}


The result of this study gave a basic knowledge of the character of vector $N$. virescens origin endemic and non-endemic areas that need a more in depth study of the geographic and ecological variation. However, the result of this study could be used to arrange a basic strategy in the management of tungro disease vectors, especially in an effort to suppress the spread of rice tungro virus in the field. Management of insect vectors, especially vector migration and also prevention of the spread of the tungro virus from endemic areas to nonendemic areas is needed. The transfer of rice seedlings should be avoided.

\section{CONCLUSIONS}

Based on the dendrogram, there were possibility of genetic differences between the populations of $N$. virescens from endemic and non endemic areas of rice tungro disease. The $N$. virescens from endemic area of tungro virus from Klaten and Sleman are genetically similar but geneticaly separate with the N. virescens from non endemic of Purwodadi, Pacitan and Ngawi. Basic knowledge of the character of vector $N$. virescens from endemic and non endemic areas need to be studied further, espesially on their geographic and ecological variation.

\section{ACKNOWLEDGEMENTS}

Financial support of the research came from the Directorate General of Higher Education, Ministry of Education (Grant No. 2881/H27/KU/2010) by Fundamental Research Grant, so we gratefully acknowledged.

\section{REFERENCES}

Azzam O \& Chancellor TCB. 2002. The biology, epidemiology, and management of rice tungro disease in Asia. Plant Dis. 86:88-100.

Black WC, DuTeau NM, Puterka GJ, Nechols JR, \& Pettorini JM. 1992. Use of the random amplified polymorphic DNA polymerase chain reaction (RAPD-PCR) to detect DNA polymorphisms in aphid (Homoptera: Aphididae). Bull. Entomol. Res. 82: 151-159.

Brooker RJ. 1999. Genetics: Analysis and Principles. An Imprint of Addison Wesley Longman, Inc. Menlo Park, California.
Choi IR, Cabauatan PQ, \& Cabunagan RC. 2009. Rice Tungro Disease. International Rice Research Institute (IRRI): Page 1-4. http:// www.knowledgebank.irri.org. Downloaded at November 23, 2010.

Cooter RJ, Winder D, \& Chancellor TCB. 2000. Tethered flight activity of Nephotettix virescens (Hemiptera: Cicadellidae) in The Philippines. Bull. Entomol. Res. 90(1): 49-55.

Dahal G, Hibino H, \& Aguiero VM. 1997. Population characteristics and tungro transmission by Nephotettix virescens (Hemiptera: Cicadellidae) on selected resistant rice cultivars. Bull. Entomol. Res. 8: 387-395.

Dinas Pertanian Tanaman Pangan Provinsi Jawa Tengah. 2010. Data Serangan OPT dan Bencana Alam di Jawa Tengah. Semarang.

Fereres A \& Moreno A. 2009. Behavioural aspects influencing plant virus transmission by homopteran insects. Virus Res.141(2): 158-168.

Gray SM \& Banerjee N. 1999. Mechanisms of arthropod transmission of plant and animal viruses. Microbiol. Mol. Biol. Rev. 63(1): 128148.

Hibino H. 1996. Biology and epidemiology of rice viruses. Annu. Rev. Phytopathol. 34: 249-274.

Hidayat P, Philips TW, \& French-Constant RH 1996. Molecular and morphological characters discriminate Sitophilus oryzae and S. zeamais (Coleoptera: Curculionidae) and confirm reproductive isolation. Ann. Entomol. Soc. Am. 89(5): 645-652.

International Rice Research Institute (IRRI). 1996. Standard Evaluation System for Rice. Inger Genetic Resources (4 ${ }^{\text {th }}$ edition). Manila, Philippines.

Kavar T, Pavlovcic P, Susnik S, Meglic V, \& VirantDoberlet M. 2006. Genetic differentiation of geographically separated populations of the southern green stink bug Nezara viridula (Hemiptera: Pentatomidae). Bull. Entomol. Res. 96: 117-128.

Ling KC. 1972. Rice Virus Disease. International Rice Research Institute. Los Banos, Philippines.

Loxdale HD \& Lushai G. 1998. Molecular markers in entomology. Bull. Entomol. Res. 88(6): 577-600. 
Margaritopoulos JT, Tsitsipis JA, Zintzaras E, \& Blackman RL. 2000. Host correlated morphological variation of Myzus persicae (Hemiptera: Aphididae) population in Grecce. Bull. Entomol. Res. 90(3): 233-244.

Muralidharan K, Krishnaveni D, Rajarajeswari NVL, $\&$ Prasad ASR. 2003. Tungro epidemics and yield losses in paddy fields in India. Curr. Sci. 85(8): 1143-1147.

Naber N, El Bouhssini M, Labhilili M, Udupa SM, Nachit MM, Baum M, Lhaloui S, Benslimane A, \& El Abbouyi H. 2000. Genetic variation among populations of the Hessian fly Mayetiola destructor (Diptera: Cecidomyiidae) in Maroco and Syria. Bull. Entomol. Res. 90(3): 245-252.

Nault LR. 1997. Arthropod transmission of plant virus: a new synthesis. Ann. Entomol. Soc. Am. 90(5): 521-539.

Rampelotti FT, Ferreira A, TcacencoFA, Martins' JF da S, Grutzmacher AD, \& Prando HF. 2008. Genetic diversity of Tibraca limbativentris Stål (Hemiptera: Pentatomidae) of Santa Catarina and Rio Grande do Sul, Brazil, using RAPD. Neotrop. Entomol. 37(1): 20-29.
Supriyadi \& Wijayanti R. 2010. Karakterisasi individu wereng hijau, Nephotettix virescens Distant penular aktif virus tungro padi. J.HPT. Tropika. 10(2): 116-122.

Supriyadi, Untung K, Trisyono A, \& Yuwono T. 2004. Karakter populasi wereng hijau, Nephotettix virescens Distant (Hemiptera: Cicadellidae) di wilayah endemi dan nonendemi penyakit tungro padi. J. Perlind. Tan. Indones. 10(2): 112-120.

Stevens J \& Wall R. 1995. The use of random amplified polymorphic DNA (RAPD) analysis for studies of genetic variation in populations of the blowfly Lucilia sericata (Diptera: Calliphoridae) in Southern England. Bull. Entomol. Res. 85(4): 549-555.

Widiarta IN. 2005. Wereng hijau (Nephotettix virescens Distant): Dinamika populasi dan strategi pengendaliannya sebagai vektor penyakit tungro. J. Litbang Pertanian 24(3): 85-92. 